\title{
Vitamin D Tedavisinde Güncel Yaklaşımlar
}

\section{Canan ERSOY ${ }^{1}$, Alparslan ERSOY ${ }^{2}$}

1 Bursa Uludağ Üniversitesi Tıp Fakültesi, İç Hastalıkları Anabilim Dalı, Endokrinoloji ve Metabolizma Hastalıkları Bilim Dalı, Bursa.

2 Bursa Uludağ Üniversitesi Tıp Fakültesi, İç Hastalıkları Anabilim Dalı, Nefroloji Bilim Dalı, Bursa.

\section{ÖZET}

Vitamin D steroid yapıda bir hormon olup kemik ve mineral metabolizması için çok önemlidir. Günümüzde eksikliği ve yetersizliği giderek artan sıklıkta görülmektedir. Vitamin D eksikliğinin kemik ve mineral metabolizması dışında farklı akut ve kronik hastalıklarla ilișkili olabileceğinin gösterilmesi son yıllarda vitamin D'ye olan ilgiyi artırmıştır. Bu derlemede vitamin D, eksikliğine yol açan nedenler, tanı, tedavi ve takipte önemli faktörler ve güncel yaklaşımlar tartışılmıştır.

Anahtar Kelimeler: Vitamin D. Eksiklik. Tanı. Tedavi. Takip.

Current Approaches in Vitamin D Treatment

\section{ABSTRACT}

Vitamin D is a steroid hormone that is very important for bone and mineral metabolism. Nowadays, deficiency or insufficiency of vitamin D is seen in increasing frequency. The fact that vitamin D deficiency may be associated with different acute and chronic diseases other than bone and mineral metabolism increased the interest to vitamin D in recent years. In this review, vitamin D, reasons leading to its deficiency, important factors and current approaches in diagnosis, treatment and follow-up are discussed.

Key Words: Vitamin D. Deficiency. Diagnosis. Treatment. Follow-up.

Vitamin D, paratiroid hormon (PTH) ve kalsitoninle birlikte kemik, kalsiyum ve fosfor metabolizmasını etkileyen çok önemli bir hormondur. Vücutta eksikliği, yetersizliği veya fazlalığı önemli problemlere yol açmaktadır. Günümüzde pek çok faktörün katkısıyla vitamin $\mathrm{D}$ eksikliği veya yetersizliği yaygın olarak görülmeye başlanmış, dünyada ve ülkemizde önemli bir sağlı sorunu haline gelmiştir ${ }^{1-4}$.

Vitamin D, steroid yapida bir hormondur. \%80-90 oranında deride 7 dihidrokolesterolden ultraviyole (UV) B aracılığı ile üretilir. Geri kalan \%10-20'lik kısım yağlı balıklardan, bitkisel kaynaklardan ve vitamin D ile zenginleştirilmiş gıdalardan alınır. Vitamin D bir prehormondur. Karaciğer ve böbrek aracıl1ğ1 ile aktif hale getirilir (Şekil 1) ${ }^{1,5}$. Dolaşımda yakla-

Geliş Tarihi: 20 Şubat 2019

Kabul Tarihi: 08 Nisan 2019

\section{Dr. Canan ERSOY}

Bursa Uludağ Üniversitesi Tıp Fakültesi,

İç Hastalıkları Anabilim Dalı,

Endokrinoloji ve Metabolizma Hastalıkları Bilim Dalı, 16059, Görükle BURSA

Tel.: 02242951113

E-posta: ecanan@uludag.edu.tr ş1k \%85'i vitamin D bağlayan proteine (DBP), geri kalanı albumine ve diğer lipoproteinlere bağlanarak taşınır. Vitamin D'nin \%1'den azı serbest haldedir. Serum dişında ağırlıklı olarak yağ dokusu, kas ve karaciğerde bulunur. Vitamin D reseptörüne (VDR) bağlanarak etkisini gösterir. VDR pek çok doku ve hücrede yaygın olarak bulunmaktadır. Vitamin D ince barsakta kalsiyum, fosfor ve magnezyum emilimini arttırırken, kemikte mineralizasyonu sağlar ${ }^{1,6}$.

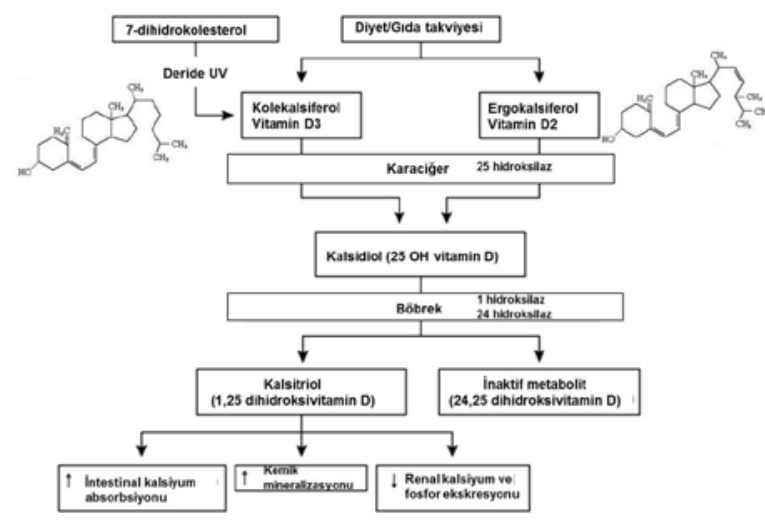

Şekil 1:

Vitamin D'nin sentezi, aktifleştirilmesi ve etkileri (Kaynak 5'ten uyarlanmıştır) 
Güneşten gelen kısa dalga boylu UVB 1şınlarının (290-315 nm) dünyaya ulaştığı açı vitamin D sentezinde etkilidir. UVB ışınları açık havada atmosfere dik açıyla gelirse ve başka bir fiziksel etkenle karşılaşmazsa hedefe ulaşabilir. Vitamin D sentezi için özellikle "güneşin dik geldiği öğle saatlerinde yani gölgenizin boyunuzdan daha kısa olduğu saatlerde" güneşe çıkılması ve 15-20 dakika kalınması önerilse de özellikle yaz aylarında öğle saatlerinde güneş çarpmalarına karşı dikkatli olunmalıdır. Güneş 1şınlarının yatık geldiği öğle saatleri dışındaki saatlerde güneşlenildiğinde, daha fazla etkili olan uzun dalga boylu UVA 1şınları etkisiyle bronzlaşılır ancak vitamin D seviyeleri düşük kalır. Serum vitamin D düzeyleri mevsimsel değişim göstermektedir. Yaz mevsimi sonunda en yüksek, kış mevsimi sonunda en düşük değerlerine ulaşmaktadır. Bulunduğumuz enlemde vitamin D sentezi Mayıs-Kasım ayları arasında gerçekleşir. Uygun 1şın açısı genellikle saat 10.00-15.00 arasındadır. Yaz aylarında uygun saatlerde tüm vücudun güneş 1şı̆̆1 ile minimal eritem dozu oluşturacak şekilde karşılaşması oral alınan yaklaşık 20000 internasyonel ünite (IU) vitamin D dozuna eşdeğer düzeyde vitamin D sentezini, sadece el, kol ve bacakların güneşe maruz kalması ise yaklaşık 3000 IU vitamin D sentezini sağlar. Açık cilt rengi olanlarda minimal eritem dozuna yaklaşık 15 dakikada ulaşılır. Cilt rengi koyu olan kişilerde minimal eritem dozuna ulaşma süresi açık cilt rengi olanlardan 3-4 kat daha uzundur. Faktör düzeyi $\geq 15$ olan güneş koruyucu kremler güneş 1şınlarının deriye ulaşmasını engelleyerek vitamin D sentezini engeller. Cam arkasından güneşlenme de aynı şekilde vitamin D sentezini engeller ${ }^{2,7}$.

\section{Vitamin D Düzeyinin Sınıflandırılması}

Serumda ölçülen 25 hidroksi $(\mathrm{OH})$ vitamin D düzeyine göre sınıflandırma yapılmaktadır. Buna göre vitamin D düzeyi yeterli, yetersiz, eksik veya ciddi eksik olabilir (Tablo I). Gereğinden fazla vitamin D alınmas1 sonucunda ise intoksikasyon düzeylerine [serum vitamin D düzeyi >150 nanogram/mililitre (ng/mL)] ulaşılabilir ${ }^{2}$.

Tablo I. Vitamin D düzeyinin serumda ölçülen değerlere göre sinıflandırılması ${ }^{1,2}$

\begin{tabular}{|l|l|}
\hline \multicolumn{1}{|c|}{ Vitamin D durumu } & \multicolumn{1}{c|}{ Vitamin D düzeyi } \\
\hline Yeterlilik & $>30 \mathrm{ng} / \mathrm{mL}(75 \mathrm{nmol} / \mathrm{L})$ \\
\hline Yetersizlik & $20-30 \mathrm{ng} / \mathrm{mL}(50-75 \mathrm{nmol} / \mathrm{L})$ \\
\hline Eksiklik & $<20 \mathrm{ng} / \mathrm{mL}(50 \mathrm{nmol} / \mathrm{L})$ \\
\hline Ciddi eksiklik & $<10 \mathrm{ng} / \mathrm{mL}(25 \mathrm{nmol} / \mathrm{L})$ \\
\hline
\end{tabular}

ng/mL'yi, nmol/L'ye çevirmek için 2.496 ile çarpmak gereklidir.

Osteomalazi yani ciddi vitamin D eksikliği (serum vitamin $\mathrm{D}$ düzeyi $<10 \mathrm{ng} / \mathrm{mL}$ ) nadiren görülse de vitamin D eksiklikleri oldukça yaygındır. 20 yaş ve üzerindeki erişkinlerde bildirilen sıklık yaklaşık \%41.6' dır ${ }^{8-10}$. Ülkemizde yapılan farklı çalışmalarda erişkinlerde vitamin D eksikliği sıklığ 1 \%33-75 gibi farklı ve yüksek oranlarda bildirilmektedir ${ }^{4,11,12}$.

Serumda 25(OH) vitamin D'nin PTH'u en efektif baskıladığı düzey 27.5-30 ng/mL'dir. 25(OH) vitamin D düzeyi eksik $(<20 \mathrm{ng} / \mathrm{mL})$ olanların \%40'ında ve ciddi eksik $(<10 \mathrm{ng} / \mathrm{mL})$ olanların $\% 51$ 'inde serum kalsiyum düzeyleri azalma eğiliminde olduğu için PTH artmıştır yani sekonder hiperparatiroidi görülür. Yeterli intestinal kalsiyum emilimi yapabilmesi için $25(\mathrm{OH})$ vitamin $\mathrm{D}$ serum düzeyinin en azından $>4.4$ $\mathrm{ng} / \mathrm{mL}$ olması gereklidir. Kırık riskini azaltan vitamin D düzeyi ise yapılan çalışmalarda $28-40 \mathrm{ng} / \mathrm{mL}$ olarak bildirilmektedir $^{13-16}$. Vitamin D eksikliği ya da direnci yapan nedenler çeşitli ve önemlidir. Bunların başında deri sentezinde azalma ve alım yetersizliği gelmektedir (Tablo II).

Tablo II. Vitamin D eksikliğine yol açan nedenler ve bunlarla ilişkili durumlar ${ }^{2-4,6}$

\begin{tabular}{|c|c|}
\hline Yetersiz alım veya emilim & $\begin{array}{c}\text { Diyet ilişkili, malabsorbsiyon, gastrik } \\
\text { bypass (bariatrik cerrahi, } \\
\text { gastrektomi), ince barsak hastalığı, } \\
\text { pankreatik yetmezlik }\end{array}$ \\
\hline Deri sentezinin azalması & $\begin{array}{c}\text { Yetersiz güneş maruziyeti, güneş } \\
\text { koruyucu kullanımı, koyu cilt rengi, } \\
\text { hava kirliliği }\end{array}$ \\
\hline $\begin{array}{c}\text { Vitamin D } \\
\text { katabolizmasında artış }\end{array}$ & $\begin{array}{l}\text { Antikonvülzanlar (fenitoin, fenobarbi- } \\
\text { tal), antifungal ilaçlar (ketokonazol), } \\
\text { antitüberküloz ilaçlar (rifampisin, } \\
\text { izoniazid), anti-retroviral ilaçlar, } \\
\text { glukokortikoidler }\end{array}$ \\
\hline $\begin{array}{l}\text { D vitamini bağlayıcı } \\
\text { proteinin kaybı }\end{array}$ & Nefrotik sendrom \\
\hline Defektif 25 hidroksilasyon & Siroz, karaciğer yetmezliği \\
\hline Defektif 1 hidroksilasyon & $\begin{array}{l}\text { Hipoparatiroidi, renal yetmezlik, } \\
1 \text { alfa hidroksilaz eksikliği }\end{array}$ \\
\hline $\begin{array}{c}\text { Kalsitriole yetersiz organ } \\
\text { yanıtı }\end{array}$ & Herediter vitamin D rezistan rikets \\
\hline Diğerleri & Yaş, obezite, genetik \\
\hline
\end{tabular}

Tarama amaçlı rutin vitamin D ölçümü önerilmemekle birlikte yüksek riskli gruplarda vitamin D ölçümü yapılması önerilir. Vitamin D eksikliği riski yüksek olan gruplar yaşlilar, koyu cilt rengine sahip olanlar, obezler, vitamin D metabolizmasını hızlandıran ilaç kullananlar, güneşe yetersiz maruziyeti olanlar, travma olmaksızın spontan kırık oluşumu öyküsü bulunanlar, osteoporoz, osteomalazi, malabsorbsiyon sendromu (çölyak hastalığı, inflamatuvar barsak hastalığı gibi), kronik böbrek yetmezliği, kronik karaciğer hastalığı ve hiperparatiroidisi olanlardır ${ }^{1-4,17}$.

Vitamini D eksikliğinde klinik bulgular vitamin D eksikliğinin derecesi ve süresine bağlıdır. Çoğu erişkin hasta asemptomatiktir. Çocuklarda büyüme plaklar1 kapanmadan önce vitamin D eksikliği rikets gelişi- 


\section{Vitamin D Tedavisinde Güncel Yaklaşımlar}

mi ile sonuçlanırken, erişkin yaş grubunda ağır ve uzamış vitamin D eksikliğinde, kemik mineral yoğunluğunda azalmanın yanı sıra osteomalazi, yaygın kemik-kas ağrısı, kemik hassasiyeti, kas güçsüzlüğü, yürüme zorluğu ve kırıklar gelişebilir ${ }^{1,2}$.

\section{Vitamini D Düzeyinin Değerlendirilmesinde Labo- ratuvar Ölçümleri}

Vitamin D durumu yarı ömrü 2-3 hafta olan serum 25(OH)D düzeyi ölçümü ile değerlendirilmelidir. Yarı ömrü kısa (4 saat) ve kan konsantrasyonu çok düşük olan 1,25 dihidroksi[(OH)2] vitamin D ölçümü tanıda kullanılmaz. 25(OH) vitamin D'nin güvenilir ölçümü yüksek performanslı sıvı kromatografisi (HPLC) ve sivi kromatografi/tandem mass spectrometry (LC/MS) ile yapılmaktadır ${ }^{1,2}$. Vitamin D eksikliği saptanan, 25(OH)D düzeyi $<20$ ng/mL olanlarda yapılması önerilen diğer testler; kanda kalsiyum, fosfor, albumin, alkalen fosfataz, parathormon, kreatinin, doku transglutaminaz antikoru ve 24 saatlik idrarda kalsiyum ölçümüdür. Düzeltilmişs serum total kalsiyumu hesaplanmalıdır: \{Düzeltilmiş serum total kalsiyumu = Ölçülen serum total kalsiyumu + ([4 - Ölçülen serum albumini] $\mathrm{x}$ 0,8) $\}^{2,5}$. Gerekli görülen olgularda düz grafiler ve dual enerji $\mathrm{x}$ ray absorbsiyometri (Dexa) yapılmalıdir ${ }^{2,5}$.

\section{Günlük Vitamin D İhtiyacının Değerlendirilmesi}

Günlük vitamin D ihtiyacı yeterli güneşe çıkılması ve balık tüketimini de içeren sağlıklı beslenme ile sağlanabilir, ancak gerekli ise vitamin D eksikliğinin önlenmesi için önerilen günlük vitamin D dozları tüm 70 yaş ve altı erişkinlerde $600 \mathrm{IU} /$ gün ve 70 yaş üstü erișkinlerde $800 \mathrm{IU} /$ gündür [vitamin D tedavisinde 40 $\mathrm{IU}=1$ mikrogram (mcg) $]^{1,2,17}$. Vitamin D eksikliğine bağlı yaşlı kişilerde kırık riskini ve olası düşme riskini önlemek için 800 IU (20 mcg)/gün vitamin D ve $>20$ ng/mL, (çok az kişide $>30$ ng/mL) 25(OH)D düzeyleri yeterli olmaktadır ${ }^{18}$. Gebelikte serum 25(OH)D düzeyi en az $20 \mathrm{ng} / \mathrm{mL}$ olmalıdır. Gebelik ve emzirme dönemi de dahil olmak üzere tüm üreme çağındaki kadınlar için günlük 600-800 IU (15-20 mcg) vitamin D önerilmektedir $^{17}$.

Vitamin D'nin yanı sıra tüm hastalarda, günlük kalsiyum alımı (diyet+destek) $1000 \mathrm{mg}$ (19-70 yaş için) ila $1200 \mathrm{mg}$ (51-70 yaş kadınlar ve $\geq 71$ yaş tüm yetişkinler için) kadar olmalıdır. Malabsorpsiyonu olan hastalarda daha yüksek bir kalsiyum dozu gerekebilir ${ }^{17}$.

\section{Vitamin D Tedavisi}

$\mathrm{D}$ vitamini düzeyinin $<30 \mathrm{ng} / \mathrm{mL}$ olması tedavi gerektirir. Tedavide vitamin D2 (Ergokalsiferol) kullanılması önerilmez, vitamin D3 (Kolekalsiferol) kullanılır. Vitamin D3 endojen olarak 25(OH)D düzeylerini daha hızlı yükseltir. Vitamin D2 DBP'e daha az bağlandığ için serbest kısım daha hızlı metabolize edilerek or- tamdan uzaklaştırılır. 25(OH)D düzeylerini yükseltmede yetersiz kalır ${ }^{1}$.

25(OH)D düzeyi $<10 \mathrm{ng} / \mathrm{mL}$ olanlarda 6-8 hafta boyunca haftada bir kez 50.000 IU vitamin D yüklemesi yapılmalıdır. Sonra günde 800 IU idame ile devam edilebilir. 25(OH)D düzeyi $10-20 \mathrm{ng} / \mathrm{mL}$ olanlarda 800-1000 IU vitamin D başlanması yeterlidir. $25(\mathrm{OH}) \mathrm{D}$ düzeyi $20-30 \mathrm{ng} / \mathrm{mL}$ olanlarda ise $600-800$ IU vitamin D başlanabilir. Yaklaşık 2-3 aylık bir tedavi sonrası hedef düzeylere ulaşılamazsa daha yüksek dozlarda verilmesi gerekli olabilir ${ }^{1,2,17}$.

Gebelerde eksikliği durumunda 600-800 IU/gün vitamin D yavaş olarak yerine konulabilir. 25(OH)D düzeylerini >30 ng/mL'de tutmak için de 1000-2000 IU/gün vitamin D yeterli olur. Üriner kalsiyum atılımı hamilelikte arttığı için, özellikle böbrek taşı öyküsü olan kadınlar vitamin D eksikliği tedavisi sırasında dikkatle izlenmelidir ${ }^{19}$

Günlük 500-700 IU vitamin D3 alımı menopoz sonras1 kadınlarda serum 25(OH)D düzeyini $20 \mathrm{ng} / \mathrm{mL}$ 'nin üzerine çıkarır. Kalsiyum ile birlikte $800 \mathrm{IU} /$ gün vitamin D desteği kırık insidensini \%20 oranında azaltabilir. Osteoporoz veya düşmeyi önlemek için gereken dozlardan daha fazla vitamin D desteği uygulanması önerilmemektedir ${ }^{20}$.

Vitamin D eksikliği olan bazı hastalarda, birlikte primer hiperparatiroidizm de görülebilir. Primer ve sekonder hiperparatiroidizm birlikteliğinde Vitamin D eksikliği ciddi ise başlangıçta hiperkalsemi belirgin olmayabilir (normal veya normalin üst sınırında), ancak PTH düzeyleri belirgin yüksektir. Bu kişilerde hiperkalsemi ve hiperkalsiüri gelişebileceği için vitamin D desteği dikkatle yapılmalıdır. Yalnızca sekonder hiperparatiroidizmi olanlarda primer ve sekonder hiperparatiroidizm birlikteliğinden farklı olarak serum kalsiyum düzeyleri genellikle normal veya normalin alt sınırındadır, PTH düzeyleri hafif yüksektir ve PTH düzeyi, vitamin D tedavisi ile normale döner. Vitamin D eksikliği sonucu sekonder hiperparatiroidizm gelişenlerde idrar kalsiyumu düşüktür ve vitamin D replasmanına rağmen iskelet iyileşmesi meydana geldiği için haftalar veya aylar içinde normale dönmeyebilir. Primer ve sekonder hiperparatiroidizm birlikteliğinde idrar kalsiyumu düşük veya normal bulunabilir ancak vitamin D desteği ile hızla yükselir ${ }^{17}$.

Obezlerde, vitamin D metabolizmasını hızlandıran ilaç kullananlarda, malabsorbisyon sendromlarında replasman dozu 2-3 kat fazla olmalıdır. Bu durumlarda tedavi planlaması yükleme 6-8 hafta boyunca 100000 IU/hafta olarak; ardından idame 3000-6000 IU/gün ile yapılabilir $^{1,2}$. Yüksek doz kullanımlarda yan etki yönünden hastalar dikkatli ve yakın takip edilmelidir. Yüksek doz vitamin D'nin yeterli olmadığı durumlarda hidroksile vitamin D metabolitleri (kalsidiol, kalsitriol, dihydrotakisterol), UVB ile tedavi düşünülebilir. Kalsidiol başlangıç dozu 20-40 mcg/gün'dür ${ }^{17}$. 
Kronik karaciğer hastalarında vitamin D eksikliğini tedavi etmek için 25 hidroksilasyon gerektirmeyen alfa kalsidiol tercih edilir. Ciddi karaciğer hastalığ olanlarda 50-200 mcg/gün verilebilir. Yaklaşık üç ay sonra tekrar 25(OH)D ölçümü yapılır. Kronik böbrek hastalığında metabolik kemik hastalığı biyokimyasal kanıtı (hiperparatiroidizm, hiperfosfatemi) yoksa ve tahmini glomerüler filtrasyon h1zı (eGFR) >30 $\mathrm{mL} / \mathrm{dak}$ ise normal böbrek fonksiyonu olan hastalar gibi yaklaşılır. Böbrek yetmezliği ilerledikçe (eGFR<30 mL/dak), 1 hidroksilasyon gerektirmeyen kalsitriol kullanılmalıdır ${ }^{1,2}$. Kalsitriol kullanan hastalarda, 25(OH)D düzeyleri klinik vitamin D durumunu göstermez ve hiperkalsemi riski nedeniyle serum kalsiyumu izlenmelidir ${ }^{17}$.

Vitamin D tedavisinde kullanılan başlıca ilaçlar Tablo III'de gösterilmiştir ${ }^{2}$. Tedavide hedef, serum 25(OH)D düzeyini $30-50 \mathrm{ng} / \mathrm{mL}$ seviyesinde tutmaktır. Absorpsiyon kapasitesi normal olan hastalarda verilen her $100 \mathrm{IU}$ (2.5 mcg) vitamin $\mathrm{D}$, serum 25(OH)D düzeyini yaklaşık $0.7-1 \quad \mathrm{ng} / \mathrm{mL} \quad(1.75-2.5 \mathrm{nmol} / \mathrm{L})$ arttırır. 25(OH)D düzeyi 40 ng/mL'nin üzerine çıktığında artış azalır. Vitamin D'nin oral kullanımda emilim sorunu olanlarda intramüsküler kullanım önerilebilir ancak verilen dozun daha geç ve yüksek oranda emileceği göz önüne alınmalıdır. İdame doz altında takipler 3-6 ayda bir yapılmalıdır. Hiperkalsemi ve hiperkalsiüri yönünden serum kalsiyum ve 24 saatlik idrar kalsiyum düzeyi takip edilmelidir. Vitamin $\mathrm{D}$ tedavisinde yan etkiler önemlidir. Serumda 25(OH)D düzeyi >88 ng/mL olanlarda hiperkalsemi, hiperkalsiüri ve kemik kırık riski artmıştır. Bu nedenle hastaların tedavileri hedef aralık olan 30-50 ng/mL düzeyine getirilecek şekilde planlanmalı, fazla dozdan kaçınılmalıdır. Hastalar hekim kontrolünde tedavilerini sürdürmelidir ${ }^{1,2,17}$.

Tablo III. Vitamin D tedavisinde kullanılan başlıca ilaçlar (2)

\begin{tabular}{|c|c|}
\hline İçerik & Sunum şekli \\
\hline Kolekalsiferol [D3] & Damla 50.000 IU/15 mL Damla \\
& $150.000 \mathrm{IU} / 10 \mathrm{~mL}$ Ampul 300.000 \\
& IU/1 mL \\
\hline Alfa kalsidiol [25(OH) D3] & Kapsül 0.25-1 mcg \\
\hline Kalsitriol [1,25(OH)2 D3] & Kapsül 0.25-0.5 mcg \\
Ampul 1-2 mcg \\
\hline
\end{tabular}

(Vitamin D $40 \mathrm{IU}=1 \mathrm{mcg}$ )

\section{Vitamin D’nin Kemik Dışı Etkileri}

Vitamin D kemik ve kalsiyum metabolizması dışında pek çok başka hücresel fonksiyonu kontrol etmektedir. Çekirdekli hücrelerin hemen tamamında VDR bulunmaktadır. İnsan genomunun \%3’ü 1,25(OH)2 D3’ün kontrolü altındadır. Böbrek dışında en az 10 farklı dokuda 1 alfa hidroksilaz enzimi bulunmaktadır. D vitamini düşüklüğü sonucunda gelişen sekonder hiperparatiroidi vasküler etkilere yol açar. VDR yok edilmiş farelerde renin-anjiotensin-aldosteron aksı aktive olur. C reaktif protein ile 25(OH)D düzeyleri arasında ters korelasyon vardır. 1,25(OH)2 D3, endotelyal adezyon moleküllerini azaltır, nitrik oksid sentezini artırır, anti-inflamatuvar etki gösterir, vasküler düz kas hücrelerinden prostasiklin üretimini artırır ve vazodilatasyona sebep olur. D vitamini eksikliğinde insülin direnci gelişir, aterosklerotik olaylar hızlanır. Pankreas ß-hücrelerinde VDR'ler bulunmaktadır. Pankreas ß-hücreleri, 1 alfa hidroksilaz aktivitesine sahiptir. 1,25(OH)2 D3 sentezleyebilmektedir. İnsan insülin geninin promoter bölgesinde VDR bulunmaktadır. 1,25(OH)2 D3 insülin reseptör genini ve peroksizom proliferatör aktivatör reseptör- $\delta$ 'nın transkripsiyonunu indüklemektedir ${ }^{21-23}$.

Vitamin D potansiyel olarak birçok hücresel işlevi düzenleyebilir. Kemik dışında pek çok dokuda reseptörü vardır ancak farklı klinik durumlarla ilişkisi konusunda yapılan çalışmalarda sonuçlar çelişkilidir. Çok sayıda epidemiyolojik veri, kas güçsüzlüğü, kanser, enfeksiyon, multiple skleroz, otoimmünite, osteoporoz, kardiyovasküler ve metabolik (diyabet, hipertansiyon, dislipidemi, obezite) hastalıklar için en büyük riskin $<20 \mathrm{ng} / \mathrm{mL} 25(\mathrm{OH}) \mathrm{D}$ düzeyleri ile ilişkili olduğunu göstermektedir ve bu riskler daha yüksek 25(OH)D konsantrasyonlarda azalmaktadır ${ }^{1,2,4,6}$. Bununla birlikte, vitamin D desteğinin iskelet sağlığı dışında yukarıda bahsedilen hastalıkların riskini de azaltabileceği konusunda ikna edici randomize kontrollü çalışma verisi yoktur ${ }^{20,24,25}$.

Sonuç olarak; vitamin D kalsiyum ve kemik metabolizması için çok önemli bir hormondur. Ülkemizde ve dünyada farklı toplum çalışmalarında eksikliğinin veya yetersizliğinin yüksek oranlarda olduğu gösterilmiştir. Günümüzde çeşitli nedenlerle güneş 1şınlarından yeterince faydalanılamamaktadır, bu nedenle vitamin D içeren balık yağı (özellikle salmon) veya zenginleştirilmiş gıda ya da vitamin D destekleri önemlidir. Vitamin D eksikliği gelişen kişilerde ise tanı, tedavi ve takip kriterleri iyi bilinmelidir. Diğer iskelet dışı hastalıklar ile vitamin D durumunun ilişkisini ve bu durumlarda önerilecek uygun doz veya 25(OH)D eşiğini tanımlamak için ise günümüzde yeterli ve kesin kanıtlar bulunmamaktadır.

\section{Kaynaklar}

1. Pilz S, Zittermann A, Trummer C, Schwetz V, Lerchbaum E, Keppel M, Grübler M, Maerz W, Pandis M. Vitamin D testing and treatment: a narrative review of current evidence. Endocr Connect 2019;8(2):R27-R43. doi: 10.1530/EC-18-0432.

2. Türkiye Endokrinoloji ve Metabolizma Derneği, Osteoporoz ve Metabolik Kemik Hastalıkları Tanı ve Tedavi Kılavuzu, 2018.

3. Kamboj P, Dwivedi S, Toteja GS. Prevalence of hypovitaminosis D in India \& way forward. Indian J Med Res 2018;148(5):548-56. doi: 10.4103/ijmr. IJMR_1807_18

4. Hekimsoy Z, Dinç G, Kafesçiler S, Onur E, Güvenç Y, Pala T, Güçlü F, Ozmen B. Vitamin D status among adults in the Ae- 


\section{Vitamin D Tedavisinde Güncel Yaklaşımlar}

gean region of Turkey. BMC Public Health 2010;10:782. doi: 10.1186/1471-2458-10-782.

5. Pazirandeh S, Burns DL. Overview of vitamin D. UpToDate Jan 2019. https://www.uptodate.com.

6. Walsh JS, Bowles S, Evans AL. Vitamin D in obesity. Curr Opin Endocrinol Diabetes Obes 2017;24(6):389-94. doi: 10.1097/MED.0000000000000371.

7. Acarkan T. D vitamini. Bilimsel Tamamlayıcı Tıp, Regülasyon ve Nöralterapi Dergisi 2015;9(3):5-8.

8. Holick MF, Binkley NC, Bischoff-Ferrari HA, Gordon CM, Hanley DA, Heaney RP, Murad MH, Weaver CM; Endocrine Society. Evaluation, treatment, and prevention of vitamin D deficiency: an Endocrine Society clinical practice guideline. J Clin Endocrinol Metab 2011;96(7):1911-30. doi 10.1210/jc.2011-0385.

9. American Geriatrics Society Workgroup on Vitamin D Supplementation for Older Adults. Recommendations abstracted from the American Geriatrics Society Consensus Statement on vitamin D for Prevention of Falls and Their Consequences. J Am Geriatr Soc 2014;62(1):147-52. doi: 10.1111/jgs.12631.

10. Forrest KY, Stuhldreher WL. Prevalence and correlates of vitamin D deficiency in US adults. Nutr Res 2011;31(1):48-54. doi: 10.1016/j.nutres.2010.12.001.

11. Cigerli O, Parildar H, Unal AD, Tarcin O, Erdal R, Guvene Demirag N. Vitamin D deficiency is a problem for adult outpatients? A university hospital sample in Istanbul, Turkey. Public Health Nutr 2013;16(7):1306 13.doi:10.1017/S1368980012003588.

12. Atli T, Gullu S, Uysal AR, Erdogan G. The prevalence of Vitamin D deficiency and effects of ultraviolet light on Vitamin D levels in elderly Turkish population. Arch Gerontol Geriatr 2005;40(1):53-60.

13. Durazo-Arvizu RA, Dawson-Hughes B, Sempos CT, Yetley EA, Looker AC, Cao G, Harris SS, Burt VL, Carriquiry AL, Picciano MF. Three-phase model harmonizes estimates of the maximal suppression of parathyroid hormone by 25 hydroxyvitamin D in persons 65 years of age and older. J Nutr 2010;140(3):595-9. doi: 10.3945/jn.109.116681.

14. Valcour A, Blocki F, Hawkins DM, Rao SD. Effects of age and serum 25-OH-vitamin D on serum parathyroid hormone levels. J Clin Endocrinol Metab 2012;97(11):3989-95. doi: 10.1210/jc.2012-2276.

15. Need AG, O'Loughlin PD, Morris HA, Coates PS, Horowitz M, Nordin BE. Vitamin D metabolites and calcium absorption in severe vitamin D deficiency. J Bone Miner Res 2008;23(11):1859-63. doi: 10.1359/jbmr.080607.
16. Trivedi DP, Doll R, Khaw KT. Effect of four monthly oral vitamin D3 (cholecalciferol) supplementation on fractures and mortality in men and women living in the community: randomised double blind controlled trial. BMJ 2003;326(7387):469.

17. Dawson-Hughes B. Vitamin D deficiency in adults: Definition, clinical manifestations, and treatment. UpToDate Jan 2019. https://www.uptodate.com.

18. Bouillon R, Carmeliet G. Vitamin D insufficiency: Definition, diagnosis and management. Best Pract Res Clin Endocrinol Metab 2018;32(5):669-684. doi: 10.1016/j.beem.2018.09.014.

19. ACOG Committee Opinion No. 495: Vitamin D: Screening and supplementation during pregnancy. Obstet Gynecol 2011;118(1):197-8. doi: 10.1097/AOG.0b013e318227f06b.

20. Bouillon R, Van Schoor NM, Gielen E, Boonen S, Mathieu C, Vanderschueren D, Lips P. Optimal vitamin D status: a critical analysis on the basis of evidence-based medicine. J Clin Endocrinol Metab 2013;98(8):E1283-304.doi: 10.1210/jc.20131195

21. Pittas AG, Chung M, Trikalinos T, Mitri J, Brendel M, Patel K, Lichtenstein AH, Lau J, Balk EM. Systematic review: Vitamin $\mathrm{D}$ and cardiometabolic outcomes. Ann Intern Med 2010;152(5):307-14. doi: 10.7326/0003-4819-152-5201003020-00009.

22. Kayaniyil S, Vieth R, Retnakaran R, Knight JA, Qi Y, Gerstein HC, Perkins BA, Harris SB, Zinman B, Hanley AJ. Association of vitamin $\mathrm{D}$ with insulin resistance and beta-cell dysfunction in subjects at risk for type 2 diabetes. Diabetes Care 2010;33(6):1379-81. doi: 10.2337/dc09-2321.

23. Cheng S, Massaro JM, Fox CS, Larson MG, Keyes MJ, McCabe EL, Robins SJ, O'Donnell CJ, Hoffmann U, Jacques PF, Booth SL, Vasan RS, Wolf M, Wang TJ. Adiposity, cardiometabolic risk, and vitamin D status: the Framingham Heart Study. Diabetes 2010;59(1):242-8. doi: 10.2337/db09-1011.

24. Rosen CJ, Adams JS, Bikle DD, Black DM, Demay MB, Manson JE, Murad MH, Kovacs CS. The nonskeletal effects of vitamin D: an Endocrine Society scientific statement. Endocr Rev 2012;33(3):456-92. doi: 10.1210/er.2012-1000.

25. Bouillon R, Marcocci C, Carmeliet G, Bikle D, White JH, Dawson-Hughes B, Lips P, Munns CF, Lazaretti-Castro M, Giustina A, Bilezikian J. Skeletal and extra-skeletal actions of vitamin D: Current evidence and outstanding questions. Endocr Rev 2018 Oct 12. doi: 10.1210/er.2018-00126. [Epub ahead of print] 
